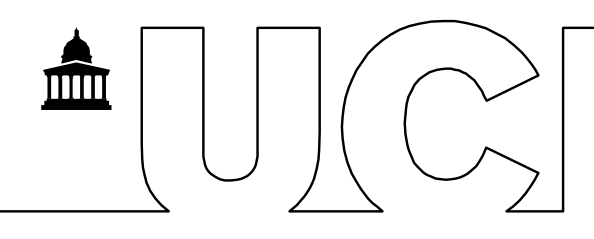

Addie, Jd; Keil, R; Olds, K; (2015) Beyond Town And Gown: Universities, Territoriality And The Mobilization Of New Urban Structures In Canada. Territory, Politics, Governance, 3 (1) pp. 27-50. 10.1080/21622671.2014.924875. Downloaded from UCL Discovery:

http://discovery.ucl.ac.uk/1447836

\title{
Beyond Town and Gown: Universities, Territoriality and The Mobilization of New Urban Structures in Canada
}

\author{
Jean-Paul D. Addie ${ }^{1}$, Roger Keil ${ }^{2}$, Kris Olds ${ }^{3}$ \\ ${ }^{1}$ Department of Science, Technology, Engineering and Public Policy, University College London \\ London, United Kingdom WC1E 6EA \\ ${ }^{2}$ Faculty of Environmental Studies, York University \\ Toronto, Ontario, Canada M3J 1 P3 \\ ${ }^{3}$ Department of Geography, University of Wisconsin-Madison \\ Madison, Wisconsin, United States 53706
}

\begin{abstract}
Cities and universities have been active participants in the creation of new economic structures, but the sociospatial relationships between "town" and "gown", and the potential impact of deepening and diversifying the relationship on either side, are neither fully understood nor simple. In this paper, we focus on universities in Canada to provide an integrative review of the changing sociospatial relations of cities and universities in an era of increasing neoliberal and globalized development agendas. We treat these relationships in spatial and institutional terms, recognizing that actors and decision-makers in government and academic bodies understand their links as a combination of both. Our analysis destabilizes established normative understandings regarding the sociospatial structure and governance of the university and the interrelations between universities and urban space. Numerous spatial strategies demonstrate that universities' relations are multi-layered, multi-scaled and multiply topological. Yet while they may be well positioned to adopt a proactive role in shaping economic development and civic agendas, universities have no privileged position in their communities. Despite acting as deliberate placemaking agents in rapidly changing metropolitan environments, universities remain located in, yet apart from, their urban and regional context.
\end{abstract}

Keywords: higher education institutions, territory, topology, urbanization, innovation, regional development

\section{Unsettling the university-territory relationship}

In December 2011, New York City's Mayor Bloomberg announced the winners of the highlypublicized "Applied Sciences NYC" competition. Beating out competing proposals from seven consortia of universities across the United States (some with partners abroad), Cornell 
University, with its partner, Israel's Technion-Israel Institute of Technology, was chosen to build a $\$ 2$ billion campus on Roosevelt Island (MCGEEHAN, 2012). In April 2012, the winning bid was further expanded to incorporate the Center for Urban Science and Progress (CUSP), to be jointly developed and funded by the City of New York, New York University, NYU-Poly, Carnegie Mellon University, the City University of New York, the Indian Institute of TechnologyBombay, the University of Toronto, and the University of Warwick. CUSP, located in nearby Brooklyn, is being designed to function as a 'living laboratory' such that it will forge relationships with key public and private agencies and organizations in New York City and ideally further the development of urban-oriented innovations in energy, transportation, water use and public health (MAXMEN, 2012). And in November 2013, the City of New York, Pittsburgh-based Carnegie Mellon University (CMU), and Brooklyn-based Steiner Studios, announced that they would create a CMU Integrative Media Program, to be located at Steiner Studios at the Brooklyn Navy Yard.

While its consequences are yet to be realized, when developed, the Applied Sciences NYC initiative intends to open the possibility for new, deep partnerships (university-university and university-business) in and across global nodes, forge new teaching and research opportunities with significant latitude for the actors involved, and establish new mechanisms for the City to access and exploit these resources. The potential of such municipality-university collaborations is now being explored by other cities. After launching a comparable competition to establish a new Institute of Technology in early 2013, the City of Amsterdam selected a consortium of TU Delft, Wageningen UR and Massachusetts Institute of Technology to develop The Amsterdam Institute for Advanced Metropolitan Solutions, utilizing a new academic space to mobilize urban technology and design (CITY OF AMSTERDAM, 2013).

The New York competition has rekindled a debate on the relationship of cities and universities. In attracting applications from 27 national and international universities, the Applied Sciences NYC project has highlighted both the deterritorialization, networked connectivity and dynamic construction of propinquity ushered in by processes of globalization, and the reterritorialization of knowledge production forged through the material and institutional production of urbanacademic space in the heart of a major global city-region. Mayor Bloomberg's request to establish an Applied Sciences Facility in New York City offers a pertinent lens disclosing the competitive urban policy prescriptions emerging at the nexus of globalization and higher education. Indeed, a public policy and institutional consensus is now crystallizing around the idea that urban regions and higher education institutions (HEls) are partners in a competitive dance that they both need to involve themselves in in order to survive (BERG, 2012).

Universities and cities are often perceived to be in a symbiotic, if sometimes complicated relationship. The geographies of global city rankings and the geographies of university rankings have shown some overlap and have been subject to recent critical review (JÖNS and HOYLER, 2013). Boston's economic success has often been credited to the strength of its metropolitan region's 53 colleges and universities while Silicon Valley has been called a spin-off of innovative research undertaken at Stanford University. The University of Waterloo is now portrayed as a product and propeller of smart urban development in the tri-city region of Cambridge, Kitchener 
and Waterloo, Ontario (GILLMOR, 2012); Blackberry problems aside. Cities and towns are parts of ecosystems of the new IT revolution that also "combine a university, an educated populace, a dynamic business community" (FRIEDMAN, 2012a, p. A23). The term "town and gown" has been used to capture this rapport. In economic geography, cities have recently been discussed in the context of innovation through creative economies that tend to be seen as a direct consequence of particular sociospatial arrangements. Global city-regions are now viewed as the location of innovation-relevant industries in producer services and the seedbed of societal and technological innovation and renewal, as well as sites of clusters of globally recognized universities (BRENNER and KEIL, 2006; OLDS, 2007; SCOTT, 2008; JÖNS and HOYLER, 2013).

Success stories in the Anglo-American context play a key discursive role in promoting universities as engines for regional development. The most prominent examples - Silicon Valley and Route 128 in Massachusetts in the United States, Cambridge in the United Kingdom, and the southeast Netherlands (e.g. ROBERTS, 1968; SAXENIAN, 1994; ETZKOWITZ, 2007; TÖDTLING, PRUD'HOMME VAN REINE and DÖRHÖFER, 2011) - have helped establish best practices and benchmarking indicators for universities seeking to contribute to their regions. Resultant policy prescriptions, embedded within the rise of the knowledge economy, are now internalized by powerful organizations and influential analysts (e.g. FLORIDA, 2005; OECD, 2007). Here, the relatively well-educated 'creative class' is considered to be the key driver of innovation and economic development (FLORIDA, 2002) while urban regions, overall, are described as the key location of growing economies (GLAESER, 2011).

However, the empirical elevation of, and myopic concentration on, a select group of clusters is problematic. Evidence across numerous national contexts has indicated that replicating the experience of successful regions in other cities and universities is no simple matter (POWER and MALMBERG, 2008; ISAKSEN and KARLSEN, 2010; TOMANEY and WRAY, 2011). In the United States, for example, major research universities including Chicago, Berkeley, Harvard and Johns Hopkins only have a marginal stimulative impact on their immediate local economies; apart from that indirectly generated by salaries, general expenditures, and sourcing dynamics (RUTHERFORD and HOLMES, 2008, p. 250; WINLING, 2011). We argue there is a need to broaden our analytical, empirical and geographic focus. The relationships of cities and universities have started to shift as globalization processes and neoliberalization agendas reconfigure the sociospatial organization of economic activity. Cities and universities have been active participants in the creation of these new economic structures. The evolving geographic nature of city-university relations destabilizes normative understandings regarding the sociospatial structure of the university and the interrelations between HEls and urban space. The relationships between "town" and "gown" and the potential impact of deepening and diversifying the relationship on either side are neither simple, nor fully understood. While there has been some tendency to view universities as mere "farm systems" and "germ plasma for innovation" for regional clusters - the Stanford-Silicon Valley relationship has been cited in this context (AULETTA, 2012) - the picture is more complex and requires concerted theoretical attention. 
In this paper, we consider whether the core ideas associated with the sociospatial structure of the university can, or should, hold firm while the sociospatial structure of societies is spreading across an increasing scale. Universities have often been theorized as placed-based institutions in urban development discourses, tied to their local situation by what COX and MAIR (1988) termed their "local dependency". However, in the current context, we suggest universities are more likely to be actors involved over multiple scales; they are global players who are highly influential beyond their immediate locale while exhibiting a significant capacity to affect the social, spatial and symbolic structures of the metropolis. We engage universities as institutions embodying multiple sociospatial relations;[1] as bounded territorial entities, spatially embedded place-making institutions, agents locating within, and producing, distinct scalar relations, and as the partnerships being forged through the Applied Sciences NYC project and Amsterdam Metropolitan Solutions clearly reveal - reticulated locales that foster new topological networks (JESSOP et al., 2008, p. 393, also see KEIL and MAHON, 2009; HARRISON, 2010). In this context, reterritorialization strategies are fundamental to universities' restructuring practices. This is clear, for example, in the establishment of domestic and international branch campuses intended to extend institutional brands and outreach, but also evident in internationalized recruitment practices for staff, students and administrators, student mobility flows and global transfers of academic knowledge that realign the spatial, operational and discursive scope of universities. Viewing the sociospatial relations of universities across these diverse geographic perspectives foregrounds the often-contradictory imperatives and missions of academic institutions. This is particularly evident as locally defined notions of territoriality - for both cities and universities - are confronted with the translocal possibilities realized through global connectivity and knowledge mobilization, technological innovations (e.g. massive open online courses [MOOCs]), and the increasingly blurred interface of academic knowledge, economic development and public policy (see AMIN, 2004; SASSEN, 2013).

Globalized urbanization raises unprecedented opportunities and profound challenges for higher education systems and institutions. One of the most visible changes is that urban regions have been on a trajectory of dispersed growth. While traditional centers tend to lose population and even economic power, people and businesses have continued to settle in the suburban or exurban reaches of urban regions despite often expressed normative preferences for creative inner city economies and compact urban living. This does not mean that all this ends in sprawl. Quite to the contrary, dispersion produces new decentralized, "in-between" and interdependent cores that often mimic the patterns of traditional centers but also lead to new qualities of urban densification (SIEVERTS, 2003; YOUNG, WOOD and KEIL, 2011). We are seeing not just the growth of the proportion of the world's population living in cities, but also the emergence of new spatial patterns and orders; ones associated with more dispersed and therefore less dense concentrations of people than in older (denser) 'urban' areas. These emerging spatial patterns have an undeniable and immediate impact on the way universities conduct their business as populations tend to relate to space and place differently now than in the past. In suburban universities such as York University in metropolitan Toronto, these consequences are already plain to see [FIGURE 1 HERE]. York enjoys successful teaching, research and research and design $(R \& D)$ synergies with the surrounding exurban belt but also increasingly with the inner suburban areas where concentrated immigrant populations and innovative businesses have 
come to be located. In smaller university towns, the pattern is replicated in a similar fashion as in the case of the Waterloo urban region and its universities, where there is a symbiotic "cooperation between business and academia, and the high levels of philanthropy and local reinvestment" (GILLMOR, 2012, p. 44).

Focusing on the Canadian context, our analysis is based on an extensive integrative review of academic and grey literatures (including government documents, newspapers, higher education blogs and online journals) that seeks to identify how higher education funders and providers are beginning to adjust institutional infrastructures, pedagogical practices, and broad ways of operating, to better serve people in places, versus drawing people to a place. We argue the Canadian context serves as a particularly relevant case to examine the territorialization processes unfurling at the nexus of globalized urbanization and neoliberalizing higher education systems and is consequently instructive for other national and institutional cases. $80 \%$ of Canada's population is now urbanized and there is broad picture of metropolitan, and especially suburban, diversity emerging across the country (FONG et al., 2005; YOUNG, WOOD and KEIL, 2011; MOOS and MENDEZ, 2013; WALKS, 2013). Extended Canadian suburbanization and the emergence of qualitatively distinct suburban ways of life reveal a model of peripheral development that is largely defined by the demographic and class diversity of new suburban populations and the immigrant experience. This changing metropolitan context, as we discuss, has profound implications for Canadian universities (all of which are public) as they attempt to adjust to new institutional and economic realities. Indeed, the shifting demands on universities to foster and commercialize innovation have resulted in a geographically-defined power struggle between institutions to ensure their funding, and centrality, within both national and international higher education systems.

This review finds universities and cities negotiating complex spatial relationships: interacting as self-interested actors (whose strategic goals may not always align) and attempting to secure locational advantages through both territorial and topological based strategies. Universities are both regionalized and globalized. However, narrow policies aimed at optimizing the economic function of universities exaggerate their apparent commercial capacities while downplaying institutions' ability to forge the soft infrastructure of local urban economies and global innovation.

\section{Placing the University and the city: From Ivory towers to economic engines and engaged universities}

The origins of the university are deeply implicated in the emergence of the city. The university and the city, though, have developed in a dynamic and complicated relationship (BENDER, 1988a; MAY and PERRY, 2006). The shifting nature of this symbiotic relation is important to note at the outset as we seek to destabilize established normative understandings regarding the sociospatial structure of the university and the interrelations between universities and urban space. Although some universities have remained in the same location, and even in the same buildings, for centuries, their spatial meaning, civic function, educational role and institutional arrangements have evolved through a series of adaptive responses to new social, economic, political, cultural and environmental demands (CALHOUN, 2006; ARBO and BENNEWORTH, 2007; COCHRANE and WILLIAMS, 2013). The establishment of distinct research agendas in 
the maturing modern universities of the nineteenth century reconfigured the mission of universities from their previous function of knowledge dissemination through teaching. This "first academic revolution" engendered a fissure between universities and the cities they were located in (RODRIGUES, 2011). As scientific enquiry strived for universalism, the modern university exhibited a "denial of place" (BENDER, 1988b, p. 8). The global expansion of suburban and rural modern campuses in the postwar period then spatially expressed the modern university as an "ivory tower" in which universal non-spatial knowledge was generated.

While such spatial imaginaries persist, the evolving function of universities (as well as HEls more broadly) alongside processes of neoliberalization and globalization have re-centered the city within the core experience and mission of many academic institutions. The increased integration of economic development into the mission of universities, including through the commercialization of knowledge represents a "second academic revolution" (ETZKOWITZ, 2007; RODRIGUES, 2011). The sociospatial structure of the university is being reconfigured; breaking away from the modern ivory tower model as institutions and governments seek to replicate the successes of Silicon Valley. Given the dynamic nature of contemporary urbanization, we expect universities, urban space and globalizing economic networks to unfurl in a rearticulated, complex, yet symbiotic relationship. The sociospatial impacts of higher education's massification and commercialization, together with the deep restructuring associated with the new knowledge economy, is of paramount importance for our understanding of contemporary urban and economic development (see SCOTT and HARDING, 2007; SMITH, 2009).

In many urban regions, universities are now portrayed as vital actors within the global knowledge economy, central players within emergent innovation systems, and active agents that can play a driving role in the innovation process and commercialization of knowledge (HUGGINS et al., 2008; DEIACO, HUGHES and MCKELVEY, 2012). Both governmental bodies and institutional administrators have embraced the potential of universities to stimulate and sustain economic growth across a number of scales (ETZKOWITZ and ZHOU, 2006; DRUCKER and GOLDSTEIN, 2007). Positioning universities as regional drivers inherently acknowledges a broadening of their mandates and a shift in the nature of university-industry and university-society relations, with universities themselves now assuming diverse development, innovation and regional leadership functions in addition to their established teaching and research missions (FREELAND, 2005; ISAKSEN and KARLSEN, 2010; LENDEL, 2010).[2]

Varying schools of thought have attempted to conceptualize the emerging geography of university entrepreneurship and knowledge transfer. The predominant scholarly approaches within the literature - including the regional innovation systems approach and its offshoot triple helix and engaged university models - adopt an economistic perspective, even when assessing the political frameworks of innovation development (ETZKOWITZ and LEYDESDORFF, 2000; HARLOE and PERRY, 2004; ETZKOWITZ, 2008; JAUHIAINEN and SUORSA, 2008; REAGER et al., 2009; UYARRA, 2010; LEYDESDORFF and DEAKIN, 2011). However, while universities can contribute to innovation, there is often an uncritical conflation in this literature between 
regional development and excellence in higher education research. Consequently, BEER and COOPER (2007) and POWER and MALMBERG (2008) both suggest current scholarship has overlooked how the university-economic development relationship is clouded by other (particularly non-economic) processes and circumstances. Further, while geographic knowledge externalities and issues of spatial proximity are central to the innovation process, the predominant conception of geography within this literature is abstract and absolute. Space relations are largely treated as instrumental; innovation networks appear separated from the contingencies of place, or divorced from broader processes of contemporary urbanization (although scholars including Susan Christopherson, Allan Cochrane, Meric Gertler and Kevin Morgan, for example, are careful in their construction of regional initiatives). As such, there is a noted lack of recognition or analysis of the co-constitutive and symbiotic relationships between HEls, regional innovation and economic development and the sociospatial dynamics of contemporary metropolitan regions. Physical, often urban, infrastructures - e.g. science, research and technology parks and business incubators - are central to universities' strategies of knowledge transfer (HUGGINS et al., 2008, p. 328), yet their impact on surrounding communities and social spaces are often a secondary concern to the production of innovation and economic growth (BENNEWORTH and HOSPERS, 2007a; COCHRANE and WILLIAMS, 2013).

Despite a perceived optimism regarding the capacity of universities to perform an increasing array of academic, economic and civic roles, UYARRA (2010) - citing a lack of evidence of the benefits and mechanisms associated with community engagement in differing types of HEls beyond a handful of anecdotal examples - questions whether they can support their increasingly broad mandates and adequately respond to multiple policy expectations. Community engagement is conditioned by the density and structure of particular universities, and the maturity of their connections within local or regional innovation systems (BOUCHER et al., 2003; LAMBERT-CHAN, 2008). Further, town and gown relationships have tended to disclose inherent tensions between universities and their surrounding communities, including conflicts over the form, function and use of urban space (e.g. insensitive development projects and campus expansions; cultural conflicts between academic and non-academic groups) and potentially exploitative relationships between students and communities as research subjects. Community-university partnerships have consequently exhibited mixed results across North American cities (LEDERER and SEASONS, 2005; MORRIS, 2005).

\section{Regional Universities, University Regionalism}

The spatial and territorial dimensions of universities have changed alongside the broadening of educational mandates and expected contributions. Despite the apparent dematerialization of production in the knowledge economy, and the increasing flexibility and mobility afforded by globalization processes, knowledge capital has tended to agglomerate in key, highly specialized niche spaces and large global city-regions. For MAY (2006, p. 339), HEl restructuring and rescaling "not only work at the level of promoting economic development, but also represent crisis management as a result of deficits and conflicts from previous [restructuring] attempts". Enhancing the political and economic function of universities can therefore be read as a 
necessary (though largely unsustainable) supporting mechanism for austerity projects and neoliberal governance.[3]

\section{Addressing reterritorialization and changing sociospatial relations}

The conceptual definition of university engagement has undergone a problematic narrowing increasingly focusing on economic concerns - since its introduction in the 1980s. The gradual economic-based targeting of engagement practices profoundly impacts universities' perception of their spatial relations and distinct spatial expressions. [4] This reductionist perspective may lead universities to overlook their diverse non-economic interdependencies with local/regional sites, resulting in the (potentially negative) reinforcement of development programs and spaceusing behaviors that ultimately influence urban competitiveness (BENNEWORTH et al., 2010, p. 1614). The pervasive trope of globalization as the driving catalyst for transformations in higher education institutions and policies provides a central rationale for the pursuit of narrow, competitive spatial roles. The relationship between $\mathrm{HEI}$ restructuring, reterritorialization and globalization, however, is more complex. In addition to the globalization-as-catalyst viewpoint, universities are active agents reshaping territorial competitiveness through their knowledge outputs. The contemporary pressures faced by both universities and cities - conditioned by their geographic fixity and local dependencies - force academic and local state institutions to reconsider their spatial relationships and, particularly for universities, their engagement with their surrounding communities, neighborhoods and regions (FREELAND, 2005; LAMBERTCHAN, 2008). The local territorialization of university-industry relations is itself dependent upon the nature and institutional capacities of the institutions and firms involved, as well as being further conditioned by the social, political and economic culture of particular places (BOUCHER et al., 2003; LAWTON SMITH, 2007).

There is an apparent tension between the spatial roles, relations and imaginaries adopted by cities, regional governance bodies and universities as they pursue (territorialized) economic development strategies, arising from divergences in each actor's local dependencies. Universities remain located both in, and apart, from their urban and regional context. Importantly, more complex, multifaceted and multiscalar understanding of educational institutions' spatiality now challenge established understandings of "functional distance" and concerns with immediate geographic proximity (BENNEWORTH and HOSPERS, 2007b; UYARRA, 2010).[5] Conceptually locating universities within territorially-embedded knowledge networks enables policy frameworks to reflexively target "a more diverse configuration of networks of universities and other actors at multiple geographies (cities, multi-regional, local) addressing different sets of development needs" (UYARRA, 2010, p. 1241). Still - in contrast to the growing consensus that universities should play a central role in regional development - the multiscalar nature of the university as a space of flows problematizes the basic notion that their spatial interests are immediately and necessarily local and as a result, higher education policy may be better focused on promoting global competitiveness rather than fostering local connectivity (POWER and MALMBERG, 2008, p. 243).

The complex spatial relations of universities presents challenges in terms of identifying and optimizing their territorial organization, but moreover impact upon the spatial conceptualizations 
utilized by universities; whether they are seeking to increase their physical and symbolic presence in core downtown districts or turning their attention to the emerging space of the suburbs. Universities and higher education networks can operate with, and within, territorially and functionally defined regional contexts, and discursively mobilize urban space to meet their ends. BOUCHER et al. (2003, p. 896) contend that traditional universities (regardless of their relative geographic centrality) "tend to be more concerned with their position in the national and international hierarchy of universities than with engaging in their region's development" given a hierarchy that privileges established institutions. Consequently newer technologically oriented universities in multiplayer core regions have exhibited a tendency to compensate for their relative marginality by deepening their engagement with their local communities. The result is a differing spatial understanding of institutions' own spatial roles and scale of operation, notably regarding city-regional space. These reconfigured spatial discourses often offer limited critical appreciation of what city-regions are, their uneven and unequal sociospatial structures, and why regional governance is important for fostering innovation and maximizing localized returns from university research and design initiatives; limitations reflected in the literature on new regionalism and learning regions more generally (MACLEOD, 2001; WARD and JONAS, 2004; ARBO and BENNEWORTH, 2007). POWELL (2007, p. 327), for example, forwards that "it is not only the academic community that needs to be creative in its outreach leadership and governance. The city-region has to permit, support and encourage creative change and, ideally, act as a driver for it".

What is often missing in these debates are accounts of inequality, sociospatial polarization and uneven development within city-regions, as well as a concern with what is actually changing in the internal and external relationships and organization of the contemporary metropolis. Policy prescriptions increasingly attempt to harness universities' potential as drivers of development at the city-regional scale yet they do so in a manner where the specific socio-economic geographies new output is supposed to benefit is rarely delineated/detailed.

Spatial sensitivity may be afforded to geographic proximity or global interconnectedness in the economic geography literature on universities, but not on the impact of changing commuter and demographic patterns and information economies on the geography of innovation and education.

\section{Adapting universities for knowledge or resource economies? Views from the center and periphery}

Human and social capital are often considered vital in the retention of locally-produced knowledge, with social capital and R\&D efforts performing markedly complementary roles in high-income regions (KOO and KIM, 2009; MIGUELEZ, MORENO and ARTIS, 2011). The impacts of public R\&D funding, however, are less pronounced in low-income regions with weak networks of untraded interdependencies (BENNEWORTH and HOSPERS, 2007a; LEJPRAS and STEPHAN, 2011). The economic, institutional, social and cultural composition of places plays a vital role in the ability of particular localities to attract and retain creative workers and knowledge-intensive firms. Differences in the relative accumulation of human capital in key urban nodes is connected to global migratory flows - including student populations, whose 
decision to invest in an education is intrinsically an investment in place - with certain cities able to realize a consistent net growth in knowledge and creative workers (BROWN, NEWBOLD and BECKSTEAD, 2010).

It is in this context that Richard Florida's creative class thesis has proved particularly influential in public policy circles. FLORIDA (2005) is critical of the "naïve" view of universities as engines of innovation which churn out ideas that are readily adaptable for industrial commercialization and regional growth. Instead, he posits the chief importance of universities as producers of knowledge and creative talent. In order to leverage universities as engines for economic growth, Florida contends federal, state and local policies need to focus on strengthening their - and their cities - attractiveness to top global talent. Analyzing the creative class thesis in Toronto census metropolitan area, GERTLER (2010, p. 10) finds that employment in creative industries expanded at a rate "more than three times" that of the total labor force. This, he reasons, is due to the influence of the Provincial government, which has provided key legislation and defined "the rules for property taxation, revenue pooling, and redistribution, as well as the framework for local and metropolitan government" (ibid, p. 10). Urban creativity has been further embraced in Toronto following Florida's arrival at the Martin Prosperity Institute in 2010, supporting the influential role of "star" academics to the marketability of place (see GERTLER, 2001; HEDGE, 2005).

Major complications exist for local and regional governments pursuing "creativity" as an economic development strategy; "glib references" to the knowledge economy obscure problems facing firms as they attempt to manage intangible, relational and knowledge-based assets and elides the fact firms have to cost-justify their outlays (MORGAN, 2004; PECK, 2005). Examining the factors influencing the attraction and retention of creative workers in Halifax, Nova Scotia, GRANT and KRONSTAL (2010) submit that while local universities provide a supply of skilled labor, the city still loses creative workers to the career opportunities and higher salaries offered in core regions such as Toronto or Vancouver. In contrast to a focus on high-technology industries or the production of human capital, FRIEDMAN (2012b) there is a need to develop an innovation agenda targeting the more efficient use of natural resources. HAWKINS (2012) has embraced such thinking, calling for Canada to focus its innovation agenda on the specific context of the nation's industrial and historical composition; thus placing extractive and resource industries at the center of a national innovation policy. Academic knowledge, following this reasoning, needs to be reconnected with the nation's industrial base to establish an accurate picture of innovation and the strengths and weaknesses of Canadian R\&D across the spectrum of national industries (BERKOWITZ, 2012).

Although Canada's economy is advantageously based upon both resource and knowledge industries, the tensions and competition between the nation's two central economic bases poses problems, particularly in the country's "have not" provinces. Canada's Atlantic provinces have looked to augment their (declining) resource-based economies by utilizing universitybased knowledge to drive innovation and economic development in locally specialized industries (WOODWARD, 2010). Rather than abandoning traditional industries in the face of globalization and the rise of knowledge and service economies, academic and state governance 
collations, such as the New Brunswick Innovation Foundation, are embracing the overlay of new technologies onto existing industrial specializations.[6] The attempted centralization of research funding by Canada's five largest research universities (the Universities of Toronto, British Columbia, Alberta, McGill and Montreal: all located in major urban centers), however, presents a distinct challenge for the development of such peripheral-region innovation agendas. In response, Eddy Campbell, President of University of New Brunswick, has called for an "equal footing" (not discursively framed as an explicit regional equalization within the nation) and funding awards based on excellence rather than a new national state strategy focused on primary global hubs, which would push universities in "have-not" provinces into predominantly teaching roles (cf. ibid).

University networks in peripheral Canadian regions are also under increasing pressure to restructure their organizational and operating arrangements. For example, in 2007, debates erupted in Newfoundland and Labrador as to whether Sir Wilfred Grenfell College should become a separate institution or continue to be part of Memorial University (NEARY, 2007). The Province initially favored establishing Grenfell College as an autonomous university, viewing institutional restructuring as a means to stimulate development and innovation. Memorial, in contrast, suggested the province would be best served by having its higher education infrastructure governed by a single, overarching governance framework to avoid duplicating services and squandering resources. Ultimately, the Grenfell campus was granted its own budget and renamed Grenfell Campus, Memorial University of Newfoundland, but this stopped short of full autonomy.

The shifting demands on Canadian universities to foster and commercialize innovation have resulted in geographically defined power struggles between institutions to ensure their funding and centrality within the national higher education system. The nation's five largest research institutions have called for a greater share of future increases in research funds in order to maintain their and, so the argument goes, Canada's global competitiveness. By contending that "resources are finite, and we have to be smart in a small country about how we use them", then University of Toronto President David Naylor framed the need to restructure the funding and base missions of universities as induced by logics of globalization: large institutions would get funding, smaller institutions in the periphery would focus on undergraduate teaching as a "free trade approach" compels institutions to find their own competitive advantages (cf. WOODWARD, 2010). In this regard, the promotion of Canada's global competitiveness may come at the expense of peripheral regions' aspirations for competitiveness within the nation.

\section{The topology, territoriality and economy of satellite campuses}

Over the past two decades, many North American universities have embraced the development of overseas satellite campuses - notably in Southeast Asia, China, and the Arab states but beachheads in Europe have also been established - as a means to increase their global connectivity and foster the benefits of internationalization for both home and overseas communities (OLDS, 2007; ALTBACH, 2011). The satellite campus model has also shifted the spatial and territorial structures of universities domestically, with the growth of regional campuses contributing to universities' concern and engagement with the health of their regions 
(BEER and COOPER, 2007). Intra-country satellite campuses offer a means for universities to expand their revenue base and institutional brand without the complications of working across international political and regulatory boundaries (FONSECA and POND, 2007; ALTBACH, 2012; LANE and KINSER, 2012).

While there is no fixed definition of a branch satellite (or branch) campus - and it is important to note there are significant distinctions between international and domestic branches, as well as between types of domestic campuses - several central tenants underlie the discursive rationale for their expansion: increasing student enrollment (notably for low-income and non-traditional students); expanding institution's brands; and enhancing regional economic development (MORRILL and BEYERS, 1991; BRISCOE and DE OLIVER, 2006; BRADY-MYEROV, 2012). The rapid growth in satellite campuses is closely tied to the geographic and economic restrictions faced by students; for instance, $79 \%$ of students in the United States attend university of college in their home state, and within a few hours' drive from home (FONSECA and POND, 2007). NIVA (2011) posits the two central goals of branch campus legislation in Washington State - increased student access and regional economic development - remain as vital now as when it was passed in the 1980s.

Canada is presently witnessing the first extensive expansion of branch campuses since the 1960s, characterized by diverse and innovative partnerships, often between universities and governmental agencies. Canadian universities, small and large, are looking to expand beyond their immediate surroundings in order to reach students, branching in to remote communities or rapidly expanding suburbs (LORINC, 2007). Marketing plays an important role for satellite campuses as they attempt to position themselves within the higher education landscape (LOWRIE and WILMOTT, 2006). Simon Fraser University, in developing a landmark suburban campus in Surrey, BC, has stressed the need to provide alternative, yet complementary, offerings to the University's other campuses (the main one in suburban Burnaby, and the second in the CBD), focusing the new campus on IT, business and entrepreneurship [FIGURE 2 HERE].

Evidence from Canada suggests university expansion strategies are proving beneficial for local young people and students from lower-income backgrounds in terms of access to educational opportunities. Students from lower-income families witnessed the largest increases in university participation following the opening of local HEIs (FRENETTE, 2007). As many (especially lowincome and non-traditional) students are tied to place by financial constraints, personal commitments, family responsibilities and lifestyle choices, they desire education options within a 30-minute commuting distance; something often impossible to achieve when commuting across metropolitan areas. Campus proximity therefore opens access by not only reducing the transportation and accommodation costs of university and college attendance, but facilitating the maintenance of social and familial commitments. The expansion of the satellite campuses reflects both a response to, and facilitation of, an expanding enrollment of non-traditional students, with the social and spatial dynamics of contemporary higher education unfurling in a symbiotic relationship. However, despite their proliferation over the past two decades, there is a paucity of research on the effectiveness of satellite campuses as educational institutions and 
their impact in reshaping urban spaces in which they are embedded.[7] Further research is required to identify how universities and cities can take advantage of the relationships emerging around branch campus development.[8]

Satellite campuses have a great potential to redefine and reshape higher education and urban landscapes while opening new channels for R\&D linkages between industry and universities. Branches may be able to foster and facilitate strategies of knowledge mobilization if the campuses are established with these objectives embedded, spatially and institutionally, within their design. Satellite campuses set up with teaching mandates are less likely to engage in university-industry R\&D collaborations and as a result, will likely be less inclined to develop and support the hard infrastructure of innovation. In contrast, flagship multi-purpose campuses being developed like Applied Sciences NYC, or Amsterdam Metropolitan Solutions, demonstrates the development of satellite campuses founded upon the principles of innovation, engagement and knowledge mobilization. These facilities territorialize and bind global knowledge flows in place and in doing so, internalize new articulations of propinquity within their institutional and physical structures. Yet the capacity of satellite campuses to serve as loci for innovation and knowledge transfer is contingent upon the relative strengths, maturity, sectoral composition and culture of universities, firms and the state within localized regional innovation systems (see HOWELLS, RAMLOGAN and CHENG, 2012). Firms are more likely to engage in collaboration with top-tier universities over lower-tier but geographically proximate institutions (LAURSEN, REICHSTEIN and SALTER, 2011).

Although FRENETTE (2007) suggests regional branch campuses have improved access for low-income and non-traditional students, there appears to be an important geographical bias to the experience, function and success of such expansions. Questions surround the function and utility of satellite campuses in both domestic and international settings. Early studies in the United States indicated significant incongruence in terms of quality and access to library services between main and branch campuses (LEBOWITZ, 1997) while emerging distance learning techniques negatively impact upon the quality of instruction (THYER, POLK and JAMES, 1997). BRISCOE and DE OLIVER (2006, p. 220) suggest disparities between the offerings of the University of Texas San Antonio's branch campus, "created subsequent and subordinate to the main campus", and the central suburban institution undermined the downtown branch's ability to increase access for centrally-located underprivileged residents. In this regard, we approach the expansion of satellite campuses with some skepticism. We can therefore posit the potential of such campuses to catalyze knowledge mobilization in localized environments is contingent upon a number of complex variables, with no guarantees of their effectiveness. Still, in the absence of a systematic body of research on these issues, university administrators are likely to continue the clamor to establish branch campuses and develop the technological and spatial infrastructure, lest they miss the perceived opportunities presented in the latest wave of university expansion.

\section{Mobilizing universities and the structure of the metropolis}

Universities have created a number of spatial strategies to tap into potential student populations. These involve the context-specific production of material, social and discursive 
spaces downtown, in the suburbs, or even abroad and their transformative capacities and levels of effectiveness are yet to be fully realized. The former president of the University of Toronto, David Naylor, recently spoke to the Toronto Board of Trade regarding the multisectoral strengths of the Toronto economy and the crucial part played by the region's HEIs (NAYLOR, 2012). Naylor's successor, Meric Gertler, has placed mobilizing the University of Toronto's urban situation - notably by drawing on from the Toronto region's social and cultural diversity at the heart of his vision for the University's future:

It is our great good fortune to be situated in the world's most open, cosmopolitan, and globalized city-region. Indeed, $U$ of $T$ would not be the success it is today were it not situated in one of the world's great cities. If we are to achieve our full potential in the future, we must leverage our location within this urban region of 6 million-plus people more fully (GERTLER, 2013).

Such sentiments reinforce the notably active role many Canadian universities have played, and continue to play, as place-makers in diverse urban contexts [FIGURE 3 HERE]. Former York University Vice-President of Research and Innovation, Stan Shapson argued in 2011:

York University is York Region's research and innovation university... We have a critical role to play in collaborating with entrepreneurs, industry and municipal partners to develop new ideas, products and services that will help Ontario gain a competitive advantage in the global economy. [Innovation York's] presence throughout York Region will make the world-class expertise of over 1,500 researchers integral to accelerating R\&D growth and strengthening communities where people want to work and enjoy a high quality of life (cf. MONIER-WILLIAMS, 2011).

While York University is cultivating its suburban 'hinterland', Ryerson University's President Sheldon Levy nurtures his institution's relationships with the urban core:

Ryerson University is proud to be part of the revitalization of Toronto's downtown core. With the vision and support of Councillor Kyle Rae and local business and community leaders, Yonge-Dundas and Toronto Life Square is springing to life. We are delighted to be working with AMC [Entertainment Inc.] to provide innovative classrooms designed with students in mind. This is exactly what we envisioned when we launched Ryerson's Master Plan and declared our intention to focus on 'the University as city-builder': with energetic partnerships and great ideas, our aim is to move Ryerson and Toronto forward together (cf. KEARNEY, 2008).

And on Canada's West Coast, as early as 2002 Simon Fraser University proudly declared at the occasion of establishing its operations in the city of Surrey: "SFU has a history of community outreach and an excellent record in running satellite campuses. The Harbour Centre campus has added to the vitality of downtown Vancouver for over 13 years" (ABERLE, 2002) and has since established an even stronger presence in various parts of the Vancouver region. For cities lacking such institutional and knowledge infrastructure, targeting university investment and engagement appears a vital and necessary means to stimulate local economic development and drive globalizing urban policy agendas; in 2013, Jeff Lehman, mayor of Barrie, Ontario, starred in a promotional video calling on Laurentian University to locate in that "largest Canadian city without a university campus" (LAURENTIAN UNIVERSITY, 2013). 
Urban innovation and creativity discourses and policy frameworks have predominantly focused on downtown. Many Canadian universities, from Windsor to Winnipeg, are either moving to or expanding their locations in downtown city centers. Ryerson University's expansive campus development, including significant street frontage on Toronto's Yonge Street presents a clear indication of this trend (KEARNEY, 2008). The reasons for this are twofold: many urban actors see downtown expansion as a form of urban renewal and revitalization for declining downtown cores, while universities view it as a way of simultaneously creating goodwill while gaining badly needed space. Downtown campuses offer municipalities a means to increase land values and local tax bases while boosting surrounding retailing, yet concomitantly they may increase congestion and push out community services. Despite these challenges, Michel Trocmé, a Toronto-based urban strategist, claims "the advantage urban campuses have is that they can grow in step with the market and in concert with other businesses, residential communities and other institutions that make downtowns so vibrant" (cf. D'ANDREA, 2012). In this regard, such campuses are viewed, more often than not, as attractive places to work versus in distant exurban zones.

It is important to note that universities' spatial and locational decisions are made with a mix of academic and research considerations. In many cases, universities are attempting to bolster their research presence in formerly less-recognized parts of their urban regions (less glamorous spaces in inner cities such as the Yonge Street corridor in Toronto or the Downtown Eastside in Vancouver) as well as new (Markham, Ontario; Surrey, British Columbia) and old suburbs (the Black Creek neighbourhood of Toronto). Canadian universities are also increasingly cognizant of their need to be present in these communities for recruitment of students into their academic programs. Together, these spatial strategies amount to no less than deliberate physical, social and symbolic place-making in a rapidly changing metropolitan environment. Indeed, they are targeted at both gentrifying inner city 'bohemian' neighbourhoods, and new immigrant ethnoburbs and technoburbs in the outer periphery of the urban region but accordingly respond to the diverse requirements of these varied metropolitan sociospatial structures.

\section{Discussion and Conclusion}

The relationship between the university and the city is evolving in an era of global urbanization. Processes of massification have fueled the expansion of the number and sizes of universities in most countries. Economic transitions, including the relative rise of the services industries, have generated the demand for workers with higher levels of education. More broadly, the development of the so-called 'knowledge economy' has enhanced the pressure on universities to produce both skilled labor and relevant knowledges that are increasingly defined through their capacity for commercialization. Cities, for their part, increasingly view universities as an essential infrastructural prerequisite to compete both locally and globally. The other broad contextual force reshaping the relationship of universities and cities is neoliberalization: the interlinked processes and ideologies emphasizing market-based solutions to a whole host of public policy concerns (e.g. infrastructure, transportation). Given this, and the declining level of state support for higher education, universities are searching for new streams of revenue to supplement base levels provided by the state or students (i.e. tuition). The implications of these broad shifts are being intensely debated and are not easily resolvable. It is worth considering, 
for example, the relationship between the size and economic capacity of particular universities and their specific modes of scalar selectivity and strategic action in the process of urban and regional development.[9]

Evidence from Canada supports the assertion that the location, role and function of universities are crucial to understand the relationships of geography and economy of knowledge-based economic activities. These relationships are both spatial and institutional, and actors and decision-makers in government and academic bodies understand their links as a combination of both. Cities and universities, as complex sociospatial entities, are neighbors in functional and land-use terms which has implications for social and physical infrastructure requirements (transportation, housing, social services), cultural life and the integration of everyday spatial practices. But cities and universities also relate to each other as self-interested institutional actors as both municipal bodies and decision-makers at postsecondary institutions involve themselves in policy debates and planning processes. The contemporary pressures faced by both universities and cities - conditioned by their geographic fixity, local dependencies, size, and structural capacities - are forcing academic and local state institutions to reconsider the configuration of their spatial relationships. Linear notions of functional and spatial distance/proximity are being replaced by a more complex, multifaceted and multiscalar understanding of universities' spatiality. The mobilization of new urban structures plays a varied, yet important role here as universities both respond to, and actively reshape the relational geographies of the metropolis; both in terms of their physical engagement in the built environment (as developers and landowners) and emergent engagement strategies with a diverse set of economic, political and social stakeholders. We found mirrored in these strategies the complex structure of econo-spatial relations that are typical of a globalized and largely market-determined capitalism where actors find their terrain of operations in an evolving mix of near- and far-oriented strategies. Conceptually, this also confirms the intricate mix of placebased (topological) and territorial (scalar) strategies we find present in much urban-economic activity today (KEIL and MAHON, 2009).

City-regions have opened up to demands from a rapidly globalizing economy and settled into metropolitan patterns of development through which these demands are met. This includes the simultaneous horizontalization (see for example the continued sprawl of businesses and residences across the urban region) and verticalization (see for example the increased densities of creative or financial industries in particular downtown locations) of urban economies. Universities, at their end, have at once expressed distinct loyalty to place and added new 'internationalization' strategies to their portfolio (see THEOBALD, 2008). Spatial relations are multi-layered, multi-scaled and multiply topological: formal and informal networks can range from the local to the global. Furthermore, exchange processes between universities and their urban sociospatial environment are complex and often unpredictable, place-dependent and historically situated. Outcomes cannot be forced. Universities have no privileged position in their communities, especially if the knowledge resources of higher education institutions are not used in a positive way: universities can be growth-oriented members of an urban growth machine, as much as an actor pursuing altruistic agendas of urban improvement and an institutional space facilitating public participation in the urban process. 
Universities, however, have often struggled to keep up with the depth and scale of these transformations. There is a very uneven level of awareness, within higher education institutions and funding agencies, about the nature of the above spatial relations and compounding this, there is a significant lack of capabilities to understand such evolving phenomenon. At any one time, most senior administrators do not know what their institution's "footprint" is with respect to teaching, research, and service-related activities. Universities are present and active in urbanregional environments near and far through knowledge transfer and academic operations, yet it remains less clear how knowledge transfer in these changing environments actually takes place. And to complicate matters further, the unbundling of teaching, learning, and credentializing via the emergence of competency-based degree programs, as well as the spread of online learning agendas and practices (including via MOOCs), will generate even more challenges to understanding the territoriality of HEls.

There are specific strategies that more or less deliberately act in and upon changing sociospatial relationships by motivating participation in knowledge mobilization processes by less traditional partners (suburban municipalities rather than the downtown, emergent immigrant organizations in ethnoburbs rather than established civic or business elites). But it remains to be seen how these strategies establish sustained processes of knowledge transfer rather than falling in line, eventually, with existing strategies and institutional frameworks. Indeed, the strongest relationships between universities and cities continue to focus on the production of the soft infrastructure of innovation - a well-educated and trained labor force - rather than forging new institutional or physical infrastructures for knowledge mobilization. A narrow focus on making university research more economically relevant oversells the immediate commercial capacity of the university and undersells: (1) the more far-reaching contribution universities make by generating creative human capital in urban regions; and (2) the potential impact of low value (\$) but high societal impact innovations. With this, we conclude by calling for qualitative empirical research among both emerging institutions in those peripheral and expanding urban areas and researchers and students who work there, as well as quantitative assessment of knowledge mobilization activities in order to enrich our understanding, and respond to the challenges, of higher education provision in an era of globalized urbanization.

\section{Acknowledgements}

Research for this paper has been supported through the Knowledge Synthesis program of the Social Sciences and Humanities Research Council of Canada. We wish to thank John Agnew and the Territory, Politics, Governance reviewers for their insightful comments and suggestions. We also gratefully acknowledge research work undertaken by Elena Chou and cartographic assistance from Brian Davidson and the University of Wisconsin-Madison Cartography Lab.

\section{Works Cited}

ABERLE K. (2002) SFU to establish Surrey campus. Simon Fraser University media release. http://www.sfu.ca/archive-pamr/news releases/archives/news02090201.html (accessed 10th May 2012). 
ALTBACH P. G. (2011) The branch campus bubble? Inside Higher Ed.

http://www.insidehighered.com/views/2011/07/15/essay on the challenges facing intern ational branch campuses (accessed 14th March 2012).

ALTBACH P. G. (2012) A new twist - in-country branch campuses. Inside Higher Ed. http://www.insidehighered.com/blogs/world-view/philip-altbach-new-twist\%E2\%80\%94country-branch-campuses\#.T3DHeqFiBA8.twitter (accessed 29th March 2012).

AMIN A. (2004) Regions unbound: Towards a new politics of place. Geografiska Annaler B 86(1) 33-44.

ARBO P. and BENNEWORTH P. (2007) Understanding the regional contribution of higher education institutions: A literature review. OECD, Paris.

AULETTA K. (2012) Get rich U. The New Yorker. http://www.newyorker.com/reporting/2012/04/30/120430fa fact auletta (accessed 24th April 2012).

BEER A. and COOPER J. (2007) University-regional partnership in a period of structural adjustment: Lessons from southern Adelaide's response to an automobile plant closure. European Planning Studies 15(8) 1063-1084.

BENDER T. ed (1988a) The university and the city: From medieval origins to the present. Oxford University Press, New York, NY.

BENDER T. (1988b) Introduction. In BENDER T. ed, (1988) The university and the city: From medieval origins to the present. Oxford University Press, New York, NY pp. 3-10.

BENNEWORTH P., CHARLES D. and MADANIPOUR A. (2010) Building localized interactions between universities and cities through university spatial development. European Planning Studies 18(10) 1611-1629.

BENNEWORTH P. and HOSPERS G. (2007a) Urban competitiveness in the knowledge economy: Universities as new planning animateurs. Progress in Planning 67(2) 105-197.

BENNEWORTH P. and HOSPERS G. (2007b) The new economic geography of old industrial regions: Universities as global/local pipelines. Environment \& Planning C 25(6) 779-802.

BERG N. (2012) Do cities need universities to survive? Atlantic Cities. http://www.theatlanticcities.com/jobs-and-economy/2012/01/university-city-love-affair/942/ (accessed 1st March 2012).

BERKOWITZ P. (2012) Resource industires should be central to Canada's innovation policy. University Affairs. http://www.universityaffairs.ca/resource-industries-should-be-central-tocanadas-innovation-policy.aspx (accessed 25th April 2012).

BLACKWELL R. (2012) Properity scorecard measures how cities foster business hubs. Globe and Mail 26th March 2012. http://www.theglobeandmail.com/news/national/prosperityscorecard-measures-how-cities-foster-business-hubs/article2381062/ (accessed 26th March 2012).

BOUCHER G., CONWAY C. and VAN DER MEER E. (2003) Tiers of engagement by universities in their region's development. Regional Studies 37(9) 887-897.

BRADY-MYEROV M. (2012) Private colleges branch out to other states. National Public Radio. http://www.npr.org/2012/04/04/149973228/private-colleges-branch-out-to-otherstates?sc=tw\&cc=share (accessed 10 April 2012).

BRENNER N. and KEIL R. (2006) The global cities reader. Routledge, New York, NY. 
BRISCOE F. M. and DE OLIVER M. (2006) Access to higher education: A conflict between landed interests and democratic ideals. Education and Urban Society 38(2) 204-227.

BROWN W. M., NEWBOLD B. and BECKSTEAD D. (2010) Growth and change in human capital across the Canadian urban hierarchy, 1996-2001. Urban Studies 47(7) 1571-1586.

CALHOUN C. (2006) The university and the public good. Thesis Eleven 84(1) 7-43.

CHRISTOPHERSON S., MICHIE J. and TYLER P. (2010) Regional resilience: Theoretical and empirical perspectives. Cambridge Journal of Regions, Economy and Society 3(1) 3-10.

CITY OF AMSTERDAM. (2013) AMS design contest results announced. I amsterdam. http://www.iamsterdam.com/ams\%20design\%20contest\%20results (accessed 30th January 2014).

COCHRANE, A., and WILLIAMS, R. (2013) Putting higher education in its place: The sociopolitical geographies of English universties. Policy and Polics 41(1) 43-58.

COX K. R., and MAIR A. (1988) Locality and community in the politics of local economic development. Annals of the Association of American Geographers 78(2) 307-325.

D'ANDREA C. (2012) The rise of downtown campuses. University Affairs. http://www.universityaffairs.ca/uptown-campuses-go-downtown.aspx (accessed 2nd March 2012).

DEIACO E., HUGHES A. and MCKELVEY M. (2012) University as strategic actors in the knowledge economy. Cambridge Journal of Economics 36(3) 525-541.

DRUCKER J. and GOLDSTEIN H. (2007) Assessing the regional economic development impacts of universities: A review of current approaches. International Regional Science Review 30(1) 20-46.

ETZKOWITZ H. (2007) MIT and the rise of entreprenuerial science. Routledge, New York, NY.

ETZKOWITZ H. (2008) The triple helix: University-industry-government. Routledge, New York, NY.

ETZKOWITZ H. and LEYDESDORFF L. (2000) The dynamics of innovation: From National Systems and "Mode 2" to a triple helix of university-industry-government relations. Research Policy 29(2) 109-123.

ETZKOWITZ H. and ZHOU C. (2006) Triple helix twins: Innovation and sustainability. Science and Public Policy 33(1) 77-83.

FLORIDA R. (2002) The rise of the Creative Class: And how's its transforming work, leisure, community and everyday life. Basic Books, New York, NY.

FLORIDA R. (2005) Cities and the Creative Class. Routeledge, New York, NY.

FONG E., LUK C. and OOKA E. (2005) Spatial distribution of suburban ethnic businesses. Social Science Research 34(1) 215-35.

FONSECA J. W. and POND C. P. (2007) Under the radar: Branch campuses take off. University Business. http://www.universitybusiness.com/article/under-radar-branch-campuses-take (accessed 14th March 2012).

FREELAND R. M. (2005) Universities and cities need to rethink their relationships. Chronicle of Higher Education 51 B20.

FRENETTE M. (2007) Do universities benefit local youth? Evidence from university and college participation, and graduate earnings following the creation of a new university. Statistics Canada, Ottawa, ON.

FRIEDMAN T. (2012a) So much fun, so irrelevant. New York Times 23rd January: A23. 
FRIEDMAN T. (2012b) Take the subway. New York Times 4th March: SR11.

GERTLER M. (2001) Best practice? Geography, learning and the institutional limits of strong convergence. Journal of Economic Geography 1(1) 5-26.

GERTLER M. (2010) Rules of the game: The place of institutions in regional economic change. Regional Studies 44(1) 1-15.

GERTLER M. (2013) Installation address on the occasion of his installation as the $16^{\text {th }}$ president of the University of Toronto. Office of the President, University of Toronto. http://www.president.utoronto.ca/installation-address (accessed 11th November 2013).

GILLMOR D. (2012) The invention of Waterloo. The Walrus 9 44-49.

GLAESER E. (2011) Triumph of the city: How our greatest invention makes us richer, smarter, greener, healthier and happier. Penguin, New York, NY.

GRANT J. and KRONSTAL K. (2010) The social dynamics of attracting talent in Halifax. Canadian Geographer 54(3) 347-365.

HARLOE M. and PERRY B. (2004) University, localities and regional development: The emergence of the 'mode 2' university. International Journal of Urban and Regional Research 28(1) 212-223.

HARRISON J. (2010) Networks of connectivity, territorial fragmentation, uneven development: The new politics of city-regionalism. Political Geography 29(1) 17-27.

HAWKINS R. (2012) Looking at innovation from a uniquely Canadian pespective: The case for a new alliance of practice, policy and scholarship. Institute for Science, Society and Policy, Ottawa, ON.

HEDGE D. (2005) Public and private universities: Unequal sources of regional innovation? Economic Development Quarterly 19(4) 373-386.

HOWELLS J., RAMLOGAN R. and CHENG S.-L. (2012) Innovation and university collaboration: Paradox and complexity within the knowledge economy. Cambridge Journal of Economics 36(3) 703-721.

HUGGINS R., JOHNSTON A. and STEFFENSON R. (2008) Universities, knowledge networks and regional policy. Cambridge Journal of Regions, Economy and Society 1(2) 321-340.

ISAKSEN A. and KARLSEN J. (2010) Different modes of innovation and the challenge of connecting university and industry: Case studies of two regional industries in Norway. European Planning Studies 18(12) 1994-2008.

JAUHIAINEN J. S. and SUORSA K. (2008) Triple helix in the periphery: The case of Multipolis in Northern Finland. Cambridge Journal of Regions, Economy and Society 1(2) 285-301.

JESSOP B., BRENNER N. and JONES M. (2008) Theorizing sociospatial relations. Environment and Planning D: Society \& Space 26(3) 389-401.

JÖNS H. and HOYLER M. (2013) Global geographies of higher education: The perspective of world university rankings. Geoforum 46(1) 45-59.

KEARNEY H. (2008) Rolling out the red carpet for innovation education. Ryerson University media release.

http://www.ryerson.ca/news/media/General Public/2008Archive/20080916 mr amc.html (accessed 10th May 2012).

KEIL R. and MAHON R. eds. (2009) Leviathan undone? Towards a political economy of scale. University of British Columbia Press, Vancouver, BC. 
KOO J. and KIM T.-E. (2009) When R\&D matters for regional growth: A tripod approach. Papers in Regional Science 88(4) 825-840.

LAMBERT-CHAN M. (2008) The university as economic engine. University Affairs. http://www.universityaffairs.ca/the-university-as-economic-engine.aspx (accessed 2nd March 2012).

LANE J. and KINSER K. (2012) Cross-border higher education: A complicated mix of players. Chronicle of Higher Education. http://chronicle.com/blogs/worldwise/cross-border-highereducation-a-complicated-mix-of-players/29206 (accessed 7th March 2012).

LAURENTIAN UNIVERSITY (2013) It's time for a university campus in Barrie [video]. Laurentian University. http://laurentian.ca/itstime (accessed 4th March 2014).

LAURSEN K., REICHSTEIN T. and SALTER A. (2011) Exploring the effect of Geographical proximity and university quality on university-industry collaboration in the United Kingdom. Regional Studies 45(4) 507-523.

LAWTON SMITH H. (2007) Universities, innovation, and territorial development: A review of the evidence. Environment \& Planning C 25(1) 98-114.

LEBOWITZ G. (1997) Library services to distant students: An equity issue. The Journal of Academic Librarianship 23(4) 303-308.

LEDERER J. and SEASONS M. (2005) Understanding the university-community alliance: The Waterloo experience. Canadian Journal of Urban Research 14(2) 237-260.

LEJPRAS A. and STEPHAN A. (2011) Locational conditions, cooperation, and innovativeness: Evidence from research and company spin-offs. Annals of Regional Science 46(3) 543575.

LENDEL I. (2010) The impact of research universities on regional economies: The concept of university products. Economic Development Quarterly 24(3) 210-230.

LEYDESDORFF L. and DEAKIN M. (2011) The triple-helix model of smart cities: A neoevolutionary perspective. Journal of Urban Technology 18(2) 53-63.

LORINC J. (2007) Branching out. University Affairs. http://www.universityaffairs.ca/branchingout.aspx (accessed 2nd March 2012).

LOWRIE A. and WILMOTT H. (2006) Marketing higher education: The promotion of relevance and the relevance of promotion. Social Epistemology 20(3-4) 221-240.

MACLEOD G. (2001) New regionalism reconsidered: Globalization and the remaking of political economic space. International Journal of Urban and Regional Research 25(4) 804-829.

MAXMEN A. (2012) Urban science centre born in the Big Apple. Nature.com. http://blogs.nature.com/news/2012/04/urban-science-centre-born-in-the-big-apple.html (accessed 10th May 2012).

MAY T. (2006) Universities: Space, governance and transformation. Social Epistemology 20(34) 333-345.

MAY T. and PERRY B. (2006) Cities, knowledge and universities: Transformations in the image of the intangible. Social Epistemology 20(3-4) 259-282.

MCGEEHAN P. (2012) City Room; N.Y.U. reaches a deal with the City to create a School of Applied Science in Brooklyn. New York Times http://query.nytimes.com/gst/fullpage.html?res=9C06E6DB1239F937A15757C0A9649D8B 63\&ref=patrickmcgeehan (accessed 13th May 2013). 
MIGUELEZ E., MORENO R. and ARTIS M. (2011) Does social capital reinforce technological inputs in the creation of knowledge? Evidence from the Spanish regions. Regional Studies 45(8) 1019-1038.

MONIER-WILLIAMS E. (2011) York University launches commercialization presence in York Region. York University Media Relations. http://news.yorku.ca/2011/02/03/york-universitylaunches-commercialization-presence-in-york-region/ (accessed 10th May 2012).

MOOS M. and MENDEZ P. (2013) Suburbanization and the remaking of metropolitan Canada. In R. KEIL ed. Suburban constellations: Governance, land and infrastructure in the $21^{\text {st }}$ Century. Jovis, Berlin, pp. 106-117.

MORGAN K. (2004) The exaggerated death of geography: Learning, proximity and territorial innovation systems. Journal of Economic Geography 4(1) 3-21.

MORRILL R. and BEYERS W. (1991) Locating branch campuses for the University of Washington. Journal of Geography in Higher Education 15(2) 161-171.

MORRIS J. T. (2005) Town-gown ties and development. Chronicle of Higher Education 51 B14.

NAYLOR D. (2012) Why the Toronto region is Canada's innovation leader. In Address to the Toronto Board of Trade, 23rd March 23, 2012. Toronto, ON.

NEARY P. (2007) One university or two for Newfoundland and Labrador? University Affairs. http://www.universityaffairs.ca/one-university-or-two-for-newfoundland-and-labrador.aspx (accessed 2nd March 2012).

NIVA C. (2011) University branch campuses are worth the cost. HeraldNet. http://www.heraldnet.com/article/20111203/OPINION03/712049991 (accessed 14th March 2012).

ORGANIZATION FOR ECONOMIC CO-OPERATION AND DEVELOPMENT (OECD) (2007) Higher education and regions: Globally competitive, locally engaged. OECD, Paris.

OLDS K. (2007) Global assemblage: Singapore, Western universities, and the construction of a global education hub. World Development 36(6) 959-975.

PECK J. (2005) Struggling with the Creative Class. International Journal of Urban and Regional Research 29(4) 740-770.

PERRY B. (2006) Science, society and the university: A paradox of values. Social Epistemology 20(3-4) 201-219.

POWELL J. (2007) Creative universities and their creative city-regions. Industry and Higher Education 21(5) 323-335.

POWER D. and MALMBERG A. (2008) The contribution of universities to innovation and economic development: In what sense a regional problem? Cambridge Journal of Regions, Economy and Society 1(2) 233-245.

REAGER B., HOES A.-C., VAN AMSTEL-VAN SAANE M., CARSON-FLINTERMAN F. and BUNDERS J. (2009) Six guiding principles for evaluating Mode-2 strategies for sustainable development. American Journal of Evaluation 30(4) 515-537.

ROBERTS E. (1968) Entrepreneurship and technology: A basic study of innovators; how to keep and capitalize on their talents. Research Management 11 249-266.

RODRIGUES C. (2011) Universities, the second academic revolution and regional development: A tale (solely) made of "techvalleys"? European Planning Studies 19(2) 174194. 
RUTHERFORD T. and HOLMES J. (2008) Engineering networks: University-industry networks in Southern Ontario automotive industry clusters. Cambridge Journal of Regions, Economy and Society 1(2) 247-264.

SASSEN S. (2013) When territory deborders territoriality. Territory, Politics, Governance 1(1) 21-45.

SAXENIAN A. (1994) Regional advantage: Culture and competition in Silicon Valley and Route 128. Havard University Press, Cambridge, MA

SCOTT A. J. (2008) Resurgent metropolis: Economy, society and urbanization in an interconnected world. International Journal of Urban and Regional Research 32(3) 548564.

SCOTT A., and HARDING A. (2007) Introduction: Universities, 'relevance' and scale. In C. BURTSCHER, A. HARDING, A. SCOTT, and S. LASKE eds. Bright satanic mills: Universities, regional development and the knowledge economy. Ashgate, Aldershot, pp. 1-24.

SIEVERTS T. (2003) Cities without cities: An interpretation of the zwischenstadt. Spon Press, London.

SMITH D. P. (2009) 'Student geographies', urban restructuring, and the expansion of higher education. Environment \& Planning A 41(8) 1795-1804.

THEOBALD R. B. (2008) Internationalization: Institutions, people and programs in Colorado. Journal of Geography in Higher Education 32(2) 205-216.

THYER B., POLK G. and JAMES G. (1997) Distance learning in social work education: A preliminary evaluation. Journal of Social Work Education 33(2) 363-367.

TÖDTLING F., PRUD'HOMME VAN REINE P. and DÖRHÖFER S. (2011) Open innovation and regional culture - Findings from different industrial and regional settings. European Planning Studies 19(11) 1885-1907.

TOMANEY J. and WRAY F. (2011) The university and the region: An Australian perspective. International Journal of Urban and Regional Research 35(3) 913-931.

UYARRA E. (2010) Conceptualizing the regional roles of universities, implications and contradictions. European Planning Studies 18(8) 1227-1246.

WALKS R. A. (2013) Suburbanism as a way of life, slight return. Urban Studies 50(8) 1471-88.

WARD K. and JONAS A. (2004) Competitive city regionalism as a politics of space: A critical reinterpretation of the 'new regionalism'. Environment and Planning A 36(12) 2119-2139.

WINLING L. (2011) Students and the Second Ghetto: Federal legislation, urban politics, and campus planning at the University of Chicago. Journal of Planning History 10(1) 59-86.

WOLFE D. (2010) The strategic management of core cities: Path dependency and economic adjustment in resilient regions. Cambridge Journal of Regions, Economy and Society 3(1) 139-152.

WOODWARD C. (2010) Does centralizing research hurt the provinces? Chronicle of Higher Education. http://chronicle.com/article/Does-Centralizing-Research/66008/ (accessed 2nd March 2012).

YOUNG D., WOOD P. and KEIL R. eds. (2011) In-between infrastructure: Urban connectivity in an age of vulnerability. Praxis (e)Press, Keolowna, BC. 


\section{NOTES}

${ }^{1}$ We draw a conceptual distinction between universities as institutions awarding bachelors, masters and doctoral degrees and other HEls, including community colleges (which may award diplomas and bachelors degrees) and educational technology companies, such as Coursera and MIT's edX, which have pioneered the development and expansions of MOOCs.

${ }^{2}$ While certain Canadian regions are able to capitalize upon their local specializations (energy resources in Calgary, transport and logistics in Vancouver), recent studies suggest that Toronto performs well in finance, transportation and food and beverage manufacturing, the GTA is only ranked top in the (declining) auto industry (BLACKWELL, 2012).

${ }^{3}$ Universities' form and function are broadening alongside their particular missions. The OECD (2007) has called for HEls to educate a broader array of people in local areas to ensure local labor has the skills necessary to promote employability is a competitive global economy. National governments are increasingly attempting to diversify the nature of academic institutions to enhance their innovation systems' flexibility (PERRY, 2006). The resultant massification of higher education attempts to open educational opportunities for a broader section of society. However, the imperatives of neoliberalization and austerity regimes have also compelled university to pursue increased commercialization of their products and offerings while focusing on marketing themselves and developing applied specializations within the emerging, increasingly competitive world of entrepreneurial education (LEDERER and SEASONS, 2005, LOWRIE and WILMOTT, 2006).

${ }^{4}$ Universities actively change their space-using behaviour in order to exploit land holdings, attract top faculty and students and to advantage of new technological advances. At the same time, many are lobbying regional partners to enhance their competitiveness and ensure the successful development of science parks and incubators etc. These perspectives imply differing power relations and structural capacities for the actors involved (BENNEWORTH et al., 2010). ${ }^{5}$ MAY (2006, p. 342) argues university managers, as well as academics, continue to hold an aspatial view of universities and often fail to understand the changes presented by institutional and urban restructuring. Fluctuating institutional aims inhibit the necessary mobilization of institutional power - matched with available symbolic and material resources - that are vital for universities' "success at the game of scales" (also see CHRISTOPHERSON, MICHIE and TYLER, 2010, WOLFE, 2010).

${ }^{6}$ The University of New Brunswick is pursuing an innovation-driven growth strategy which attempt to position themselves at the forefront of sonar-based ocean floor mapping the analysis of materials with MRI machines, and the creation of advanced wood composites; fields directly tied to the region's resource economy (WOODWARD, 2010).

${ }^{7}$ The rapid growth of demand at satellite campuses brings significant pressure to reconfigure educational and urban space. Nipissing University's Muskoka branch (opened in 1996) rapidly outgrew its initial strip mall location and in 2008 relocated to a five-hectare downtown location on land donated by the municipality of Bracebridge (LORINC, 2007). It is important to note that to talk of university branch campuses often evoke conceptions of the university and university life (student unions, athletic facilities, libraries) which may not met by actually-existing satellites. The alternative physical environment of branch campuses may open more inclusive space for non-traditional students and adult learners looking for workplace training, yet their divergence 
from expected spatial norms has led some students to be dissatisfied with the education experience being provided (BRADY-MYEROV, 2012).

${ }^{8}$ Technological innovation is vital to enable the expansion of branch campuses. Online teaching formats allow for flexible course delivery and web-based libraries offering digital materials provide an alternative to costly physical library buildings and holdings. It is worth considering the impact of free MOOCs designed to further lifelong learning and sometimes the simple acquisition of a certificate versus a credit or a degree. In principle some of these could be structured at the city-regional scale, or across multiple city-regions, helping to facilitate the expansion of knowledge transfer and democratic education opportunities.

${ }^{9}$ We are grateful to one of the Territory, Politics, Governance reviewers for this suggestion. 


\section{FIGURES}

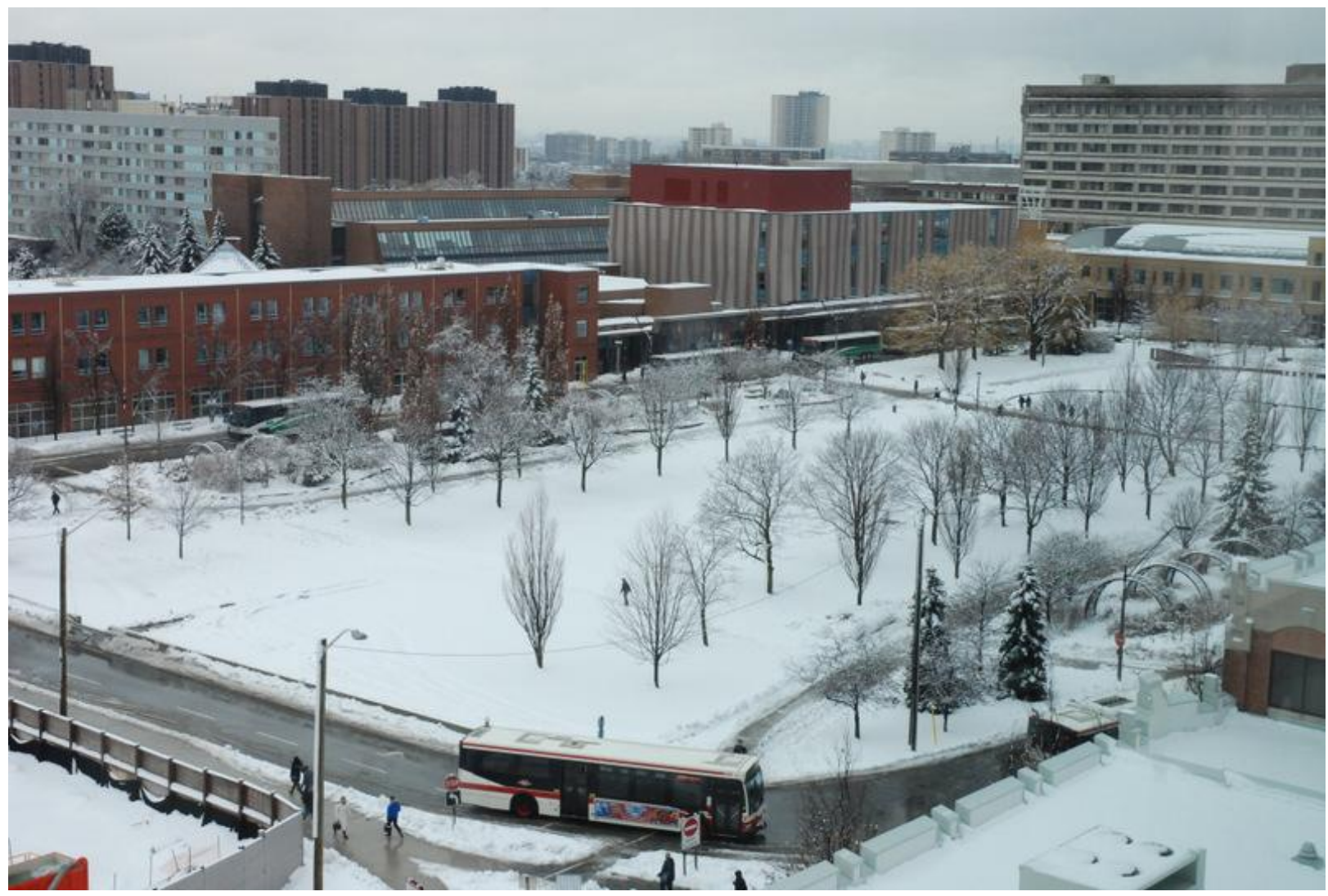

FIGURE 1: York University's Keele Campus opened in 1965 on the outskirts of the Municipality of Metropolitan Toronto but decades of urban growth mean the suburban campus is now located at the center of the Toronto city-region. The Province of Ontario's growth management and transportation plans, released between 2004 and 2008, position York University as a major regional "mobility hub" integrating diverse transit services across the Greater Toronto Area. The Keele Campus already functions as a key terminus for local, express and regional bus service while a subway connection to downtown Toronto and Vaughan Metropolitan Centre (with a station currently under construction in the bottom left of the image) is expected to open in 2016 (photo by Roger Keil). 


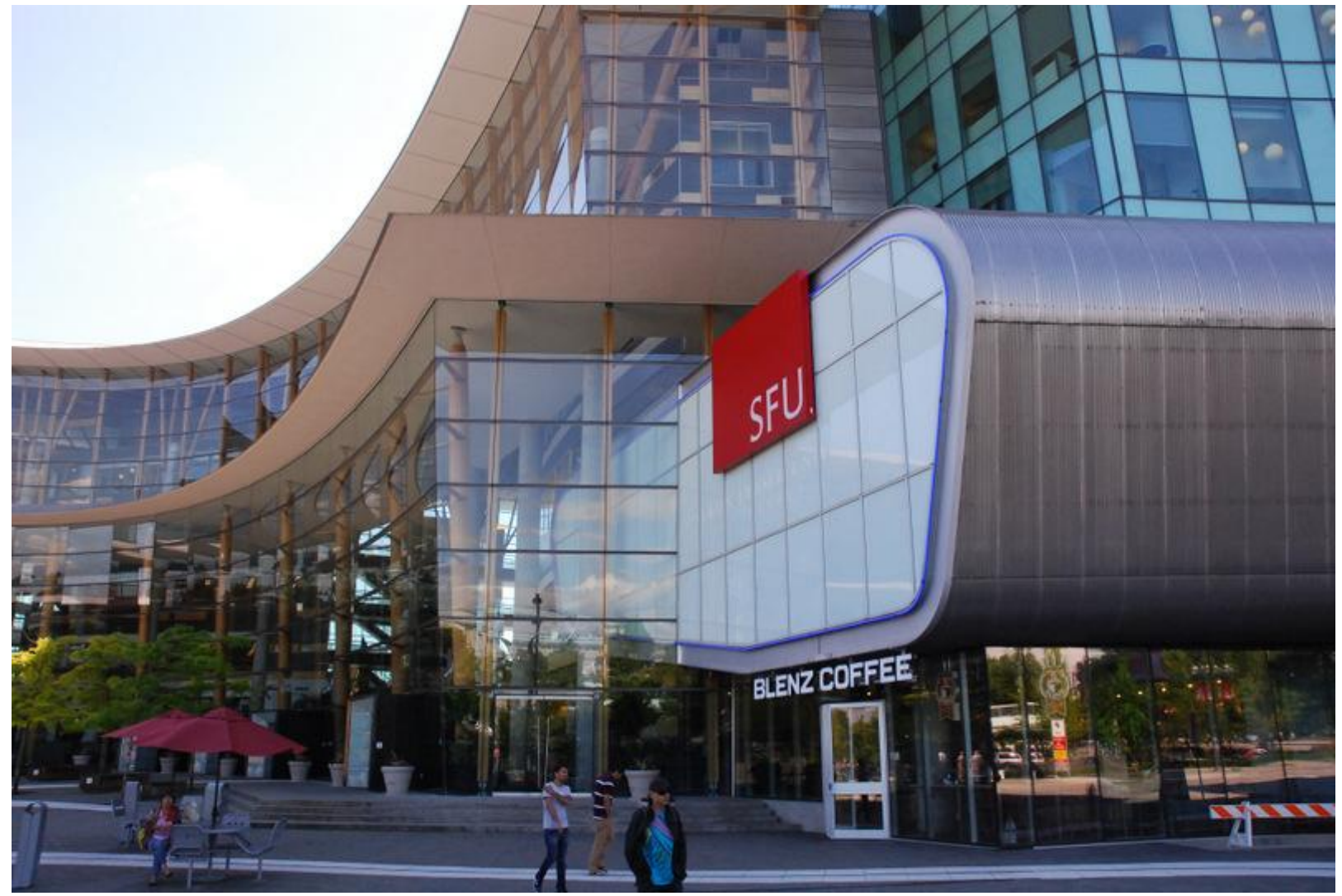

FIGURE 2: Simon Fraser University's (SFU) satellite Surrey Campus (pictured) opened at the centre of the booming suburban municipality of Surrey, BC with an enrolment of 565 students in 2002. SFU's Surrey campus represents a refocusing of the University's institutional footprint, spatial imaginary and investment into the metropolitan periphery. Illustrative of how universities, through distinct reterritorialization strategies, can respond to, and actively reshape, new urban structures, SFU's Surrey campus has expanded to incorporate new classrooms and science labs while supporting intensified development around Surrey's Central City complex (including residential and office tower construction) over its first decade of operation (photo by Roger Keil). 


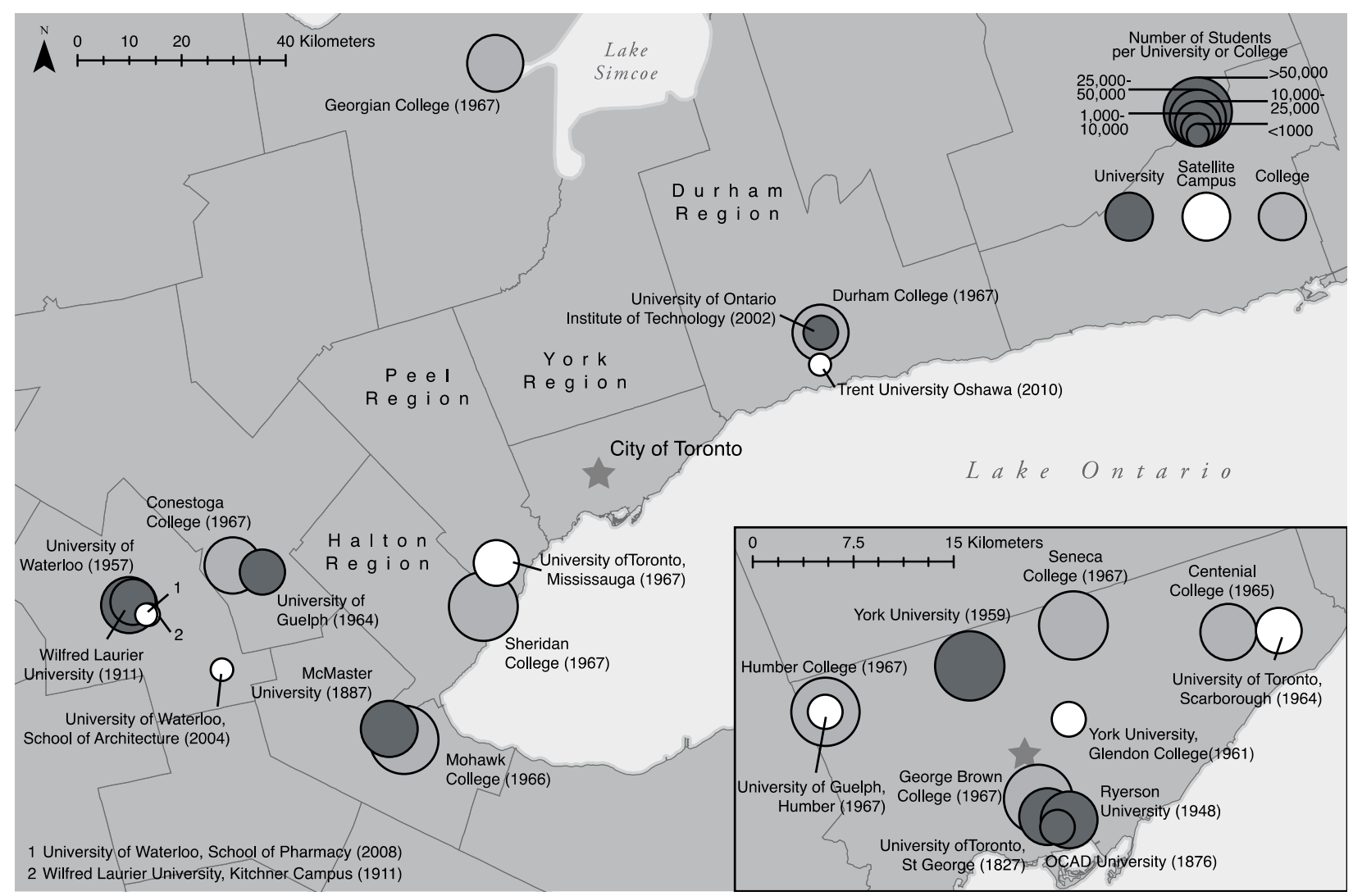

FIGURE 3: The regional presence and student populations of universities and colleges in the Greater Toronto Area, the city of Hamilton, and the Guelph, Kitchener and Waterloo tri-city area. Of particular note are, firstly, the branch campus expansions and network of colleges opened in the late-1960s that provided education to Fordist workers and their children in accordance with the spatial Keynesian projects being pursued by the Government of Ontario. Located throughout Toronto's inner suburban municipalities and the surrounding region, they now serve major student populations beyond the city core. Secondly, evidence of a post-2000 wave of (predominantly specialized) satellite campus development across southern Ontario. Data have been drawn from a search of university and college websites and represent the most current student population figures in years ranging between 2008-2013. University and satellite campus populations include undergraduate and graduate students. College populations include full-time and part-time/continuing students. The authors of this paper acknowledge the inspiration they drew for this map from a series of slides shown by Toronto City Councillor Adam Vaughan at the event Going to School, a Transit Conference for the GTHA at York University on September 28, 2012 (figure by Brian Davidson, University of Wisconsin-Madison Cartography Lab). 